\title{
Model strukturalny systemu transportu naczep drogowych na wózkach kolejowych w ruchu kombinowanym kolejowo-drogowym
}

\begin{abstract}
$W$ artykule zaprezentowano model strukturalny innowacyjnego rozwiqzania systemu transportu kombinowanego, kolejowo-drogowego. Opisano istotne różnice nowego systemu $w$ stosunku do znanych systemów transportu intermodalnego oraz wymieniono główne zalety nowego rozwiazania. Wyszczególniono podstawowe prace projektowe $i$ naukowo-badawcze niezbędne do realizacji w celu dalszego rozwoju prezentowanej koncepcji.
\end{abstract}

\section{Wstęp}

Stały wzrost ilości transportowanych towarów $\mathrm{z}$ jednoczesną troską o racjonalizowanie kosztów transportu i ochronę środowiska naturalnego wskazują na potrzebę ciagłego monitorowania stanu techniki w dziedzinie transportu drogowego i kolejowego oraz poszukiwania innowacyjnych technik transportu, w tym techniki intermodalnej, która generuje niższe koszty zewnętrzne i bardziej sprzyja środowisku naturalnemu.

Rozwój transportu intermodalnego umożliwia ograniczenie przyrostu transportu towarów drogami kołowymi i równocześnie pozwala na przyrost masy towarowej transportowanej koleją. Transport kolejowy jest zdecydowanie mniej energochłonny w odniesieniu do transportu drogowego. Polska jest jedynym dużym krajem w UE, w którym poza transportem kontenerowym nie realizuje sie przewozów intermodalnych, w szczególności drogowych naczep samochodowych. Naukowcy z IPS „Tabor” we współpracy z Politechniką Warszawską opracowali konkurencyjny do światowych konstrukcji, tabor bimodalny pozwalający rozwiązać problem ,przeniesienia” tirów z drogi na tory. Istotną barierą wdrożenia tego systemu do eksploatacji jest konieczność wyprodukowania specjalnych naczep bimodalnych, których konstrukcja jest odpowiednio skomplikowana $\mathrm{w}$ porównaniu do standardowych naczep drogowych.

Do najbardziej znanych i rozpowszechnionych w Europie i świecie systemów transportu kombinowanego, kolejowo drogowego należy zaliczyć systemy: „Ro-La” (ruchoma szosa), modalohr oraz system bimodalny. Wymienione systemy transportowe wykorzystują metodę przeładunku poziomego, bez użycia urządzeń dźwigowych za wyjątkiem systemu modalohr. Przedstawiany w niniejszym opracowaniu system łączy pewne cechy pozytywne wymienionych wyżej systemów transportowych jak również eliminuje niektóre cechy negatywne. W systemie ruchoma szosa oraz modalohr naczepy ładowane są na specjalne platformy nośne o masie własnej 8-10 ton posadowione na wózkach kolejowych. W systemie bimodalnym platformy nośne zostały wyeliminowane i zastapione urządzeniami zwanymi adapterami, na których zamocowane zostają bimodalne naczepy drogowe, które oprócz funkcji pojemnika na towar stanowią również strukturę nośną „wagonu”. Ze względu na sposób zamocowania naczepy na adapterach (podparcie naczepy na jej końcach), jest konieczne zaprojektowanie ramy naczepy o określonej wytrzymałości z reguły o masie większej o 2-3 tony w porównaniu do standardowej naczepy drogowej.

W prezentowanym systemie transportowym wyeliminowano platformy nośne występujące w systemie ruchoma szosa oraz modalohr. Naczepa jest transportowana po torze kolejowym tylko na odpowiednio zaprojektowanych wózkach kolejowych, a punkty podparcia ramy naczepy pozostaja $\mathrm{w}$ tym samym miejscu jak podczas jazdy po drodze kołowej. Zatem warunki obciążenia pionowego ramy naczepy w ufomowaniu drogowym i kolejowym pozostają bez zmian. Jednak $\mathrm{w}$ uformowaniu kolejowym na pociag złożony z naczep działają siły wzdłużne, które nie występują podczas jazdy drogowej. Wzdłużne siły występujące w uformowaniu kolejowym wprowadzono w ramę nośną naczepy w miejscach, w których przekroje belek nośnych ramy są większe niż w części przedniej to znaczy $\mathrm{w}$ miejscu przewidzianym pod ciagnik drogowy. Zatem rama naczepy może wymagać przystosowania do ich przenoszenia lub nie, dla niektórych typów naczep. Przyrost masy ramy nacze- 
py w porównaniu do standardowej naczepy drogowej będzie znacznie mniejszy niż w naczepie bimodalnej.

\section{Struktura modelu}

System transportu naczep drogowych na wózkach kolejowych (rys. 1) złożony jest $\mathrm{z}$ odpowiednio przystosowanej naczepy drogowej 1, przedniego wózka dwuosiowego 2 i tylnego wózka czteroosiowego 3. Przedni wózek 2 może być wykonany jako wózek wyposażony $\mathrm{w}$ typowe urządzenia pociagowo-zderzne 4 (rys. 2) służące do połączenia z lokomotywą i składem pociągu, lub jako wózek wyposażony w sztywne urządzenie cięgłowe 5 (rys. 1), łączące przód naczepy z tyłem sąsiedniej naczepy, lub dwa tyły sąsiednich naczep.

Przód naczepy 1 oparto na siodle 6 typu „Jost” i zamocowano do kolumny wózka 7 za pomocą połączenia sworzniowego. Urządzenie cięgłowe 8 łączy w sposób sztywny kolumnę wózka $7 \mathrm{z}$ ramą nośną naczepy 9 za pomocą sworzni 10 lub innego rodzaju urządzeń sprzęgowych.

Tył naczepy 1 spoczywa na wózku tylnym $3 \mathrm{w}$ ten sposób, że koła naczepy oparto na półkach ramy wózka i zabezpieczono płytami odchylnymi 11 i cięgłami 12. Ramę wózka połączono ze wspornikiem 13 ramy naczepy za pomocą sztywnego cięgła 14 mocowanego przegubowo do wspornika 13 ramy naczepy.
Do wspornika 13 ramy naczepy zamocowano również urządzenie cięgłowe 5 łączące sąsiednie naczepy. Mocowanie urządzenia cięgłowego $5 \mathrm{w}$ wsporniku 13 można zrealizować za pomocą urządzenia sworzniowego 15 lub innego rodzaju urządzenia sterowanego ręcznie lub automatycznie.

\section{Sposób montażu wózków pod naczepą}

Przestawienie naczepy $\mathrm{z}$ trakcji drogowej na kolejową odbywa się na płaskim terminalu wyposażonym w tor prosty zabudowany tak, aby poziom terminalu był zrównany z poziomem główek szyn toru.

Na rysunku 3 pokazano sposób i kolejność montażu wózków kolejowych pod naczepą.

\section{Faza I rys 3a}

Ustawienie wózka tylnego na torze za kołami naczepy oraz zablokowanie wózka przed możliwością toczenia się po torze. Przygotowanie wózka do najazdu naczepy przez opuszczenie płyt odchylnych 11 (przednich) oraz płyt odchylnych wewnętrznych.

\section{Faza II rys. 3b}

Najazd kół naczepy na płyty odchylne 11 . Zamocowanie wózka do naczepy za pomoca sztywnego cięgła 14. Zabezpieczenie kół drogowych przez podniesienie płyt odchylnych i ich zablokowanie zworami 12.

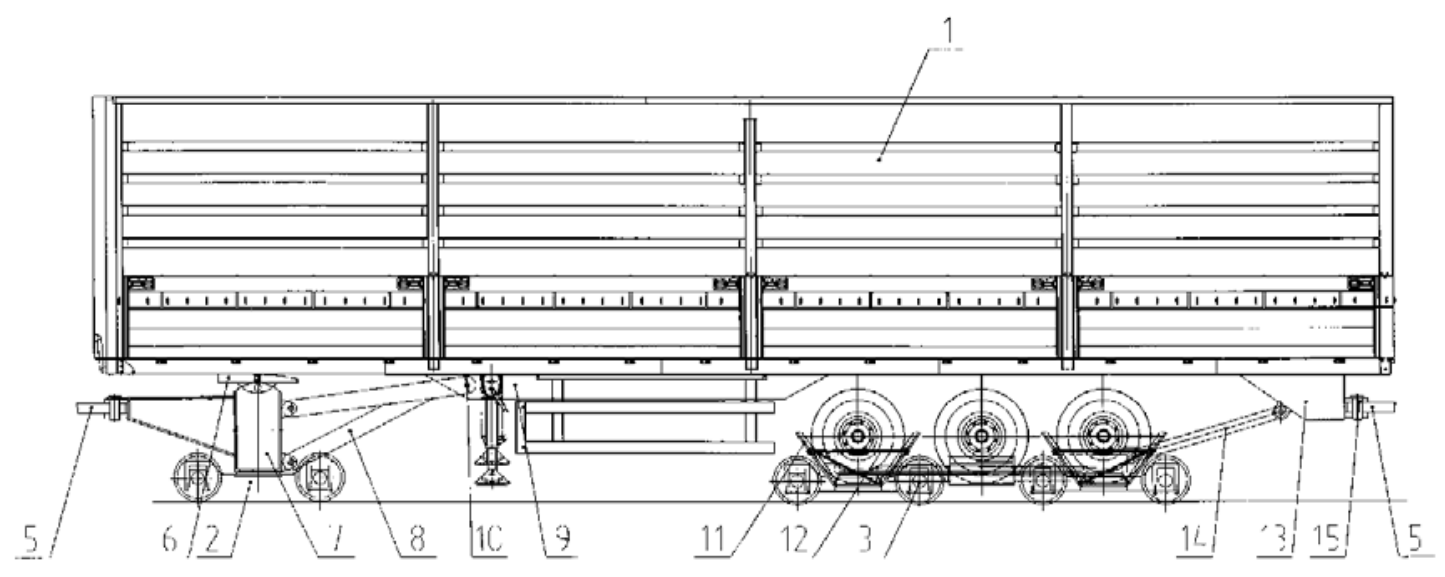

Rys. 1. Naczepa na wózkach kolejowych z wózkiem przednim przystosowanym do łączenia międzynaczepowego

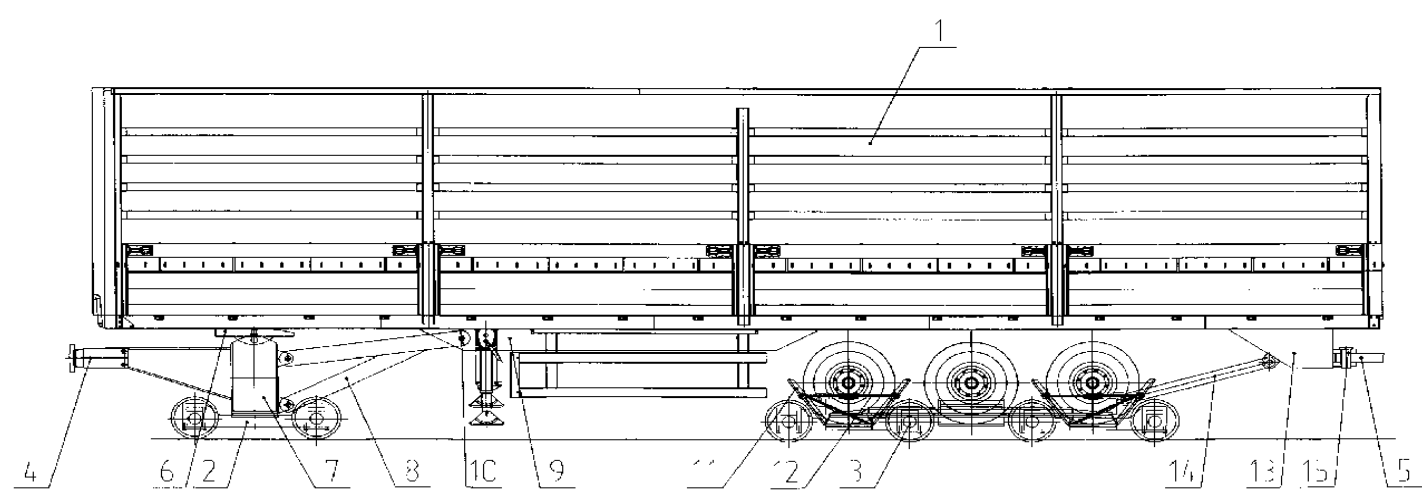

Rys. 2. Naczepa na wózkach kolejowych z wózkiem przednim wyposażonym w typowe urządzenia pociagowo-zderzne 

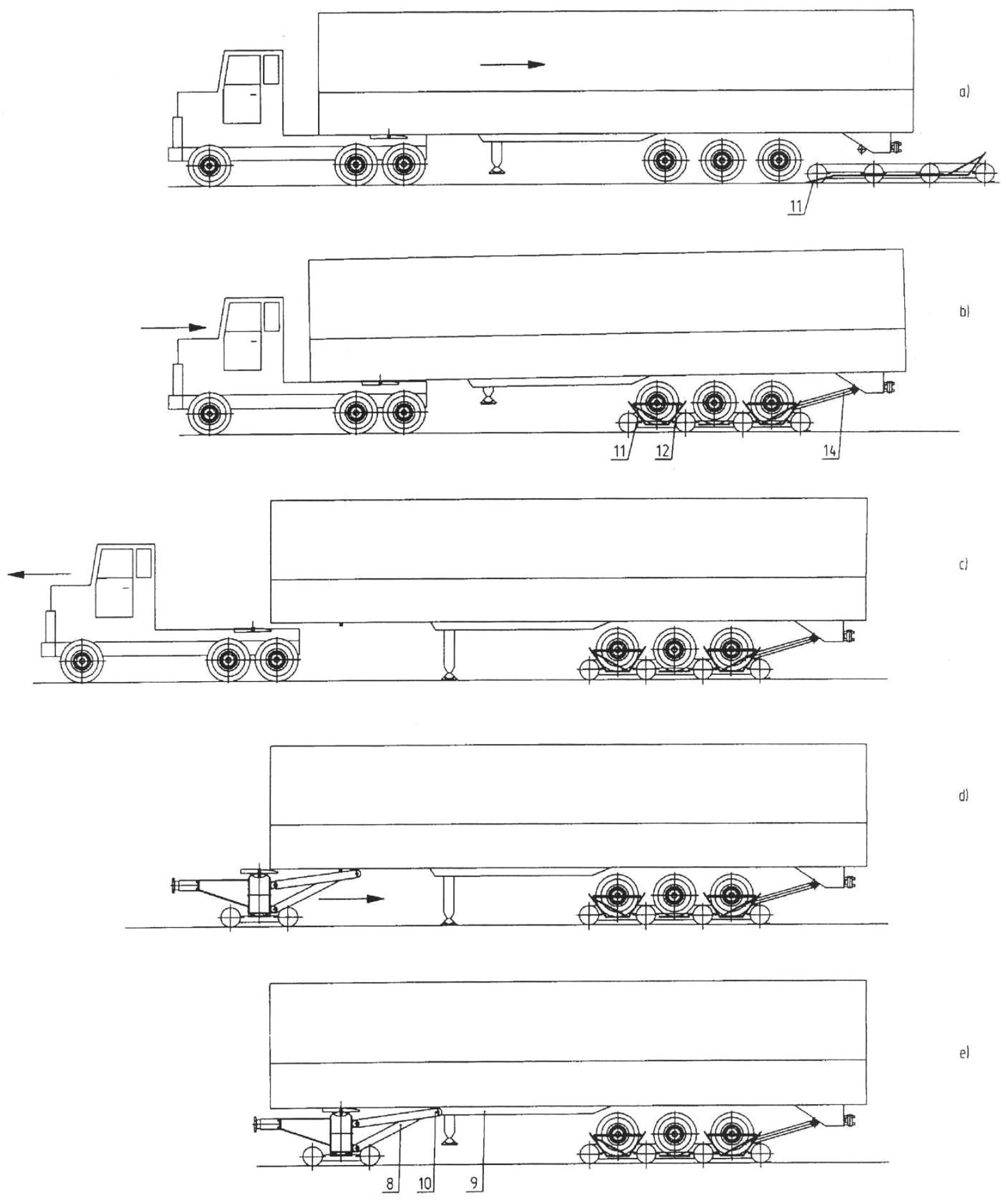

el

Rys. 3. Proces montażu wózków kolejowych pod naczepą

\section{Faza III rys. 3c}

Opuszczenie nogi podporowej i wyjazd ciagnika spod naczepy.

\section{Faza IV rys. 3d}

Wtoczenie wózka przedniego pod przód naczepy.

\section{Faza V rys. 3e}

Oparcie przodu naczepy na siodle typu „Jost” i zaryglowanie zamka siodła. Zamocowanie urządzenia cięgłowego $8 \mathrm{w}$ ramie naczepy 9 , za pomocą urządzenia ryglującego 10 . Podniesienie nogi podporowej naczepy.

\section{Alternatywne możliwości montażu składu pocią- gu}

$\mathrm{Na}$ rysunkach 4 i 5 przedstawiono przykładowo dwie metody formowania składu pociagu złożonego z naczep na wózkach kolejowych. Pierwsza metoda rys. 4 polega na jednokierunkowym łączeniu przyczep (za 


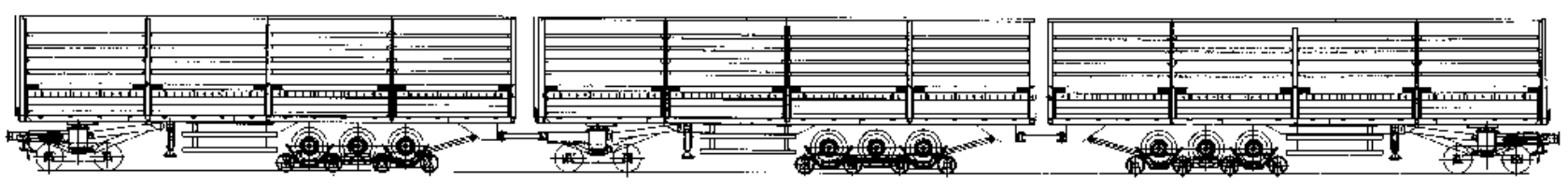

Rys. 4. Pociąg wyposażony na obu końcach w wózki z urządzeniami pociągowo-zderznymi oraz ze sztywnym połączeniem międzynaczepowym

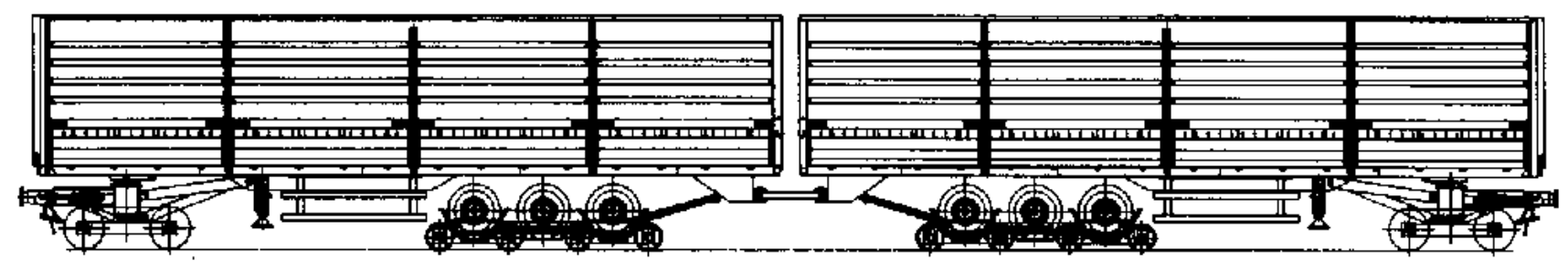

Rys. 5. Moduł dwunaczepowy wyposażony na obu końcach w urządzenia pociagowo-zderzne

wyjątkiem ostatniej naczepy), w ten sposób, że pierwsza naczepa jest wyposażona w przedni wózek zaopatrzony w urządzenia pociągowo zderzne a kolejne naczepy w przednie wózki wyposażone w wspornik do montażu sztywnego cięgła, łączącego przód kolejnej naczepy ze wspornikiem zamontowanym $\mathrm{w}$ tyle naczepy poprzedniej. Natomiast ostatnia naczepa w składzie pociągu jest odwrócona tyłem do naczepy poprzedzającej a przód naczepy jest wyposażony w wózek z urządzeniami pociaggowo zderznymi.

Druga metoda rys. 5 polega na tworzeniu dwuczłonowych zespołów naczep połączonych za pomocą urządzeń pociagowo zderznych, dwie naczepy w członie łączą się za pomocą sztywnego wzdłużnie cięgła przenoszącego siły pociagowe i ściskające, działające podczas jazdy po torach kolejowych.

Zalety eksploatacyjne rozwiązania:

- możliwość montażu naczep na wózki równocześnie dla kilku lub kilkunastu naczep, a po montażu połączenie ich w pociag (skrócenie czasu formowania składu pociagu),

- możliwość wyłączenia ze lub włączenia do składu pociagu dowolnej naczepy, znajdującej się wewnątrz składu pociagu,

- łączenie naczep w składy dwuczłonowe, zaopatrzone na końcach $\mathrm{w}$ urządzenia pociagowo zderzne pozwala na doczepienie składów dwuczłonowych na końcu pociągu towarowego (masa składu dwuczłonowego jest w przybliżeniu równa masie towarowego wagonu czteroosiowego $\sim 80 \mathrm{t}$, zatem zderzaki są zdolne do przeniesienia i pochłonięcia energii przy nabieganiu składów dwuczłonowych na ostatni wagon pociagu towarowego),

- relatywnie mały rozstaw czopów skrętu między wózkiem przednim i tylnym tworzy lepsze warunki wpisywania się naczepy w zarys skrajni taboru w porównaniu do systemów ruchoma szosa, modalohr oraz bimodalnego,
- znaczące zmniejszenie masy pociągu w porównaniu do systemów ruchoma szosa i modalohr,

- prosty terminal przeładunkowy, bez dodatkowej infrastruktury przeładunkowej.

\section{Podsumowanie}

Ze względu na nowatorski, niekonwencjonalny układ biegowy pociagu w celu dalszego rozwoju projektu należy podjąć szereg niezbędnych analiz konstrukcyjnych oraz symulacyjnych badań teoretycznych między innymi w zakresie oceny:

- bezpieczeństwa ruchu pociagu na torze prostym i na łukach,

- wytrzymałości konstrukcji naczepy oraz elementów i zespołów układu biegowego pociagu,

- kinematyki ruchu pociagu przy różnych konfiguracjach torów,

- spełnienia warunków skrajni kinematycznej wg przepisów UIC 505-1 oraz 506-1.

Oddzielnym, nie rozpoznanym szczegółowo na tym etapie prac koncepcyjnych problemem jest spełnienie wymagań dotyczących hamowania składu pociagu. Pod względem struktury budowy pociagu proponowane rozwiązanie można porównać z systemem „ruchoma szosa”, gdzie wspólnym parametrem układów biegowych jest mała średnica kół wózków kolejowych $(450 \mathrm{~mm})$. W systemie „Ro-La” zastosowano hamulec tarczowy, mocując tarcze hamulcowe na kołach osi zestawów kołowych. W prezentowanym w niniejszej publikacji rozwiązaniu, jest to niemożliwe ze względu ograniczenia wynikające z przyjętej koncepcji układu biegowego. Teoretycznie istnieją możliwości konstrukcyjne zabudowy hamulca niekonwencjonalnego, zwłaszcza, że masa „wagonu” wg prezentowanej koncepcji jest $\sim 15$ ton mniejsza od załadowanego wagonu systemu ,ruchoma szosa”. 
Proponowana nowatorska koncepcja transportu naczep drogowych w ruchu kombinowanym, kolejowo-drogowym stanowi nowe wyzwanie dla projektantów i naukowców branży taboru kolejowego. Wdrożenie do eksploatacji nowego systemu transportu intermodalnego może istotnie przyczynić się do komodalności dwóch gałęzi transportu, kolejowego i drogowego.

Zaprezentowana koncepcja systemu transportu naczep drogowych na wózkach kolejowych oraz szczegółowe rozwiązania techniczne zastosowane w projekcie zostały zgłoszone do ochrony patentowej w Urzędzie Patentowym RP.

\section{Lit e r a t u r a}

[1] Medwid M., Studium tworzenia intermodalnych środków technicznych transportu ladowego $w$ szczególności taboru bimodalnego, Rozprawy, Wydawnictwo Politechniki Poznańskiej, Poznań 2008.

[2] Medwid M., Polski system transportu kolejowodrogowego [Bimodalnego] typu „Tabor”, Monografia, Wydawnictwo IPS ,TABOR”, Poznań 2006.

[3] Medwid M., Cichy R., System transportu przyczep drogowych po torach kolejowych $i$ tramwajowych, Pojazdy Szynowe nr 2/2010, Wydawnictwo IPS , TABOR”. 